ELORE (ISSN 1456-3010), vol. 18 - 1/2011.

Julkaisija: Suomen Kansantietouden Tutkijain Seura ry.

[http://www.elore.fi/arkisto/1_11/kirjat_soderholm.pdf]

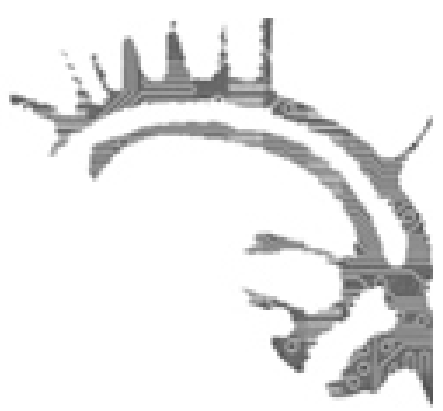

\title{
KIRJA-ARVIO
}

\section{MEdiA-ANTROPOLOGIAN HAHMOA HAKEMASSA}

SUMIALA, JOHANNA 2010. Median rituaalit - johdatus media-antropologiaan. Vastapaino: Tampere. 174 sivua.

\section{$\underline{\text { Stig Söderholm }}$}

Johanna Sumiala avaa reittiä media-antropologiaan kiinnostavasta suunnasta: tutkimuksen alustana toimii kulttuuri- ja sosiaaliantropologian klassinen rituaaliteoria ja sen uudemmat variaatiot. Kirjan alaotsikko, Jobdatus media-antropologiaan, vaikuttaa äkkiseltään luettuna joko lupaavan liikoja tai oikovan mutkia. Syy tähän ei ole välttämättä kirjoittajan, sillä ovathan kirjojen kannetkin osa sitä mediaalistunutta todellisuushahmotusta, jota Sumiala tekstissään pohtii ja problematisoi. Sinänsä mainiota, että kannessa lukijan kanssa kommunikoi nimien ja otsikoiden lisäksi vain pienikokoinen, menneitä vuosikymmeniä representoiva televisio, jonka ruudun läpi populaarikulttuurin ikonit läsnäoloistuvat. Toki Sumiala myös selkeästi ilmoittaa, että kirja ei ole kaikkia kulmia läpikäyvä esitys media-antropologiasta, vaan lähestymissuunta erityisesti teoreettisen ja tutkimushistoriallisen taustan osalta on kirjoittajan tietoisesti valitsema ja sisäistämä media-antropologian uoma.

\section{MEdiA-ANTRopologian TEOREETTINEN POHJAVIRE}

Yleisellä tasolla Sumiala luonnehtii media-antropologiaa "mediatutkimuksen ja antropologian välimaastoon sijoittuvaksi lähestymistavaksi, jossa mediaa ja sitä käyttäviä ihmisiä tutkitaan etnografian, symboli-, rituaali- ja myyttitutkimuksen" (s. 12) mahdollistamilla tavoilla. Kirjan osioista luku "Teoriaa ja johtolankoja” tarjoaa perusteellisen katsauksen muutamiin rituaalitutkimuksen klassikoihin (Durkheim, Bataille, Girard, Victor Turner); valikointi siis kohdistuu hallitsevasti rituaalitutkimuksen ranskalaiseen traditioon pienin brittiläisin maustein. Sumialan esittelemien tutkijoiden kirjoituksissa korostuvat rituaalien yhteenliittävät funktiot mutta toisaalta myös rajojen ja kieltojen 


\section{Stig Söderholm: Media-antropologian hahmoa hakemassa}

ylitykset, jolloin rituaalit nähdään myös uhraamisen tai yhtälailla uhrautumisen myötä rakentuvan sankaruuden sidoksena. Sumialan tarkastelu ei jää kuitenkaan pelkäksi tiivistetyksi oppihistorialliseksi ekskursioksi, vaan kyse on nykyhetkisen mediatutkimuksen taustojen perusteellisesta selvittämisestä. Sinänsä kiinnostavaa ja osin jopa yllättävää on, että 1990-luvun virtuaali- ja screenitodellisunden tutkimuksellinen haltuunotto palautuu paljolti viime vuosisadan ensimmäisten vuosikymmenien sosiologien ja uskontotieteilijöiden kirjoituksiin; niistä teksteistä epäilemättä löytyy moni muukin nykykulttuurin olemusta luonnehtiva ajankohtainen näkemys.

Sumialan esiin nostamista klassikoista varsinkin durkheimilainen yhteisöteoria näyttää voivan hyvin 2000-luvun kommunikaation maailmassa. Sen sijaan Victor Turnerin rituaaliteorian, ja erityisesti siihen keskeisesti sisältyvien liminaalisuuden tai liminoidisuuden ideoiden soveltaminen mediakulttuurin kontekstissa sujahtaa helposti ylitulkinnan rajoille. Sumialan käyttämä esimerkki vuoden 2001 Lahden MMhiihtojen dopingskandaalista ei oikein taivu liminoidisuus-idean kuosiin, sillä kisojen doping-tarina näyttää jatkuvan edelleenkin vuonna 2011; välitila on siis venähtänyt epämääräisen pitkäksi. Tässä mielessä voisikin olla viisasta vetää jonkinlainen erotusviiva Turnerin 1950-luvulla etnografisissa kenttätöissään tutkiman pienten traditioiden maailman ja 2010-luvun kevyiden, vaikka joskus hiukan affektipitoisten ja pääosin median kautta muotoutuvien väliaikaisyhteisöllisyyksien välille. Karnevaalien ja festivaalien tuottaman yhteisöllisyyden tutkimuksessa turnerilainen teoria vielä toimii, samoin kuin hänen teoriansa pyhiinvaelluksista ja niiden rakentumisesta soveltuu mainiosti myöhäismodernin mediakulttuurin hahmottamiseen

\section{MEdia RITUAALIEN TEKIJÄNÄ}

Kirjan toisessa osassa "Median rituaalit" Sumiala kantaa rituaaliteorian aineksia mediaviestinnän monipaikkaiselle kentälle. Sen lisäksi, että kirjoittaja käy edelleen kiinnostavaa ja hetkittäin pikkutarkkaakin terminologista ja teoreettista keskustelua (nyt kuitenkin klassikkojen sijaan lähinnä nykytutkijoiden kanssa), hän heittää lukijalle erinomaisia esimerkkejä ja analyyseja niistä rituaalisuuden muodoista ja ilmaisuista, joiden synnyssä ja kehittymisessä medialla on ratkaiseva osuus. Näitä ovat esimerkiksi julkiset ja viihteeksi kehittyneet tunnustamisrituaalit, joita käytetään hyväksi muun muassa Big Brother, Idols, Suomen Robinson ja muut Selviytyjät -tyyppisissä ohjelmissa, joissa "henkilökohtaiset asiat" tehdään tutuksi miljoonille etäkatsojille.

Kulttuurin ja yhteisöllisyyden kysymysten vakavammalle laidalle Sumiala siirtyy tarkastellessaan kuoleman medialisoituneita tuho- ja sururituaaleja. Esimerkiksi koulusurmissa on yhtäällä tietysti kyse "ei saa tappaa" -kiellon rikkomisesta ja ylittämisestä. Tämän transgression seurauksena media toisaalta myös astuu näyttämön etualalle ja "rakentaa tapahtumissa rituaalisen tilan, jossa yhteisön jäsenet voivat hoitaa kuoleman aiheuttamaa järkytystä osallistumalla yhdessä jaettuun suruun erilaisten symbolien avulla" (s. 136). Jos haluaa jatkaa Sumialan ajatustenkulkua, voisi varmasti todeta, että nykyisellään erityisesti media hallitsee ja tuottaa kollektiivisia kriisirituaaleja sanan vuosisataisessa antropologisessa (van Gennep ja myöhemmät funktionalistit) merkityksessä. Varmasti moni muistaa vieläkin, miten Suomen koulukriisien yhteydessä sellaiset 
Stig Söderholm: Media-antropologian hahmoa hakemassa

sanat ja ilmaisut kuten "yhteisö" ja "yhteisöllisyys" tai niiden häviämisen toteaminen ja niiden paluun toivominen, yhtäkkiä nousivat hallitsevaan poliittiseen diskurssiin.

\section{ENTÄ KERTOMUKSET?}

Johanna Sumialan Median rituaalit on rohkein vedoin tehty näkemys media-antropologian mahdollisuuksista rikastaa kulttuurintutkimuksen keskustelua. Kirja käy varsin hyvin yliopistojen ja korkeakoulujen aineistoksi. Sivuja kirjassa on 174, mutta asiaa siinä on 300 sivun verran. Se hämmästyttää, että kirjassa ohitetaan narratiivit kulttuurisena ilmiönä. Tarinan, kertomuksen, mukaanotto rituaalisuuden tarkasteluun olisi avannut myös väylän myyttikerronnan analyyseihin. Sumialan kirjassa myyttien olemassaolo kulttuurin perusresurssina kyllä todetaan, mutta useimmiten vain sivulauseessa ja ohimennen. Tämä on harmi, sillä rituaaleja rakenteleva media ei pärjää ilman tarinaa, sankarikertomusta tai mytologiaa.

Tätä tekstiä kirjoittaessani katson miniläppärin näytön yli television ruutua, jossa Idols-poplaulukilpailu postmodernilla nopeudella tuhoaa ja synnyttää sankareita. Tämä viimeistään vakuuttaa minut yhtäältä Sumialan kirjan ajankohtaisuudesta ja toisaalta kirjan käsittelemien teemojen vankasta pysyvyydestä.

Filosofian tohtori, dosentti Stig Söderholm toimii kulttuuriantropologian yliopistonlehtorina Itä-Suomen yliopiston filosofisessa tiedekunnassa. 